\title{
Notes on Liukiu and Formosan Plants.
}

(Continued from p. 94.)

By

\section{J. Matsumura.}

Coldenia procumbens, $L$. D.C. Prodr. vol. IX, p. 558; Clark. in Hook. f. Fl. Brit. Ind. vol. IV. p. 144; Benth. Fl. Aust. vol. IV. p. 391; Hemsl. Journ. Linn. Soc. vol. XXVI. p. 146; Henry Trans. Asiat. Soc. vol. XXIV. Suppl. p. 62.

Hab. in Formosa : ad Hong-soang (H. Kawakami, no. 17); in ruderatis ejusdem loci (Y. Tashiro, no. 83).

Calyx 5-partitus lobis oblongis acutis.

Corolla $2 \mathrm{~mm}$. alta, tubulosa, 4-lobata. Stamina 4, inclusa, filamentis brevissimis; antheris ovalibus. Nucule rugose, subspinose.

Eeliotropium indicum, L. D.C. Prodr. vol. IX. p. 556 ; Bot. Mag. \%. 1837; Clark. in Hook f. Fl. Brit. Ind. vol. IV. p. 152 ; Hemsl. Journ. Linn. Soc. vol. XXVI. p. 147 ; Henry l.c. p. 69.

Hab. in monte Urabu, ins. Yonakuni, archipelagi Yaeyama (S. Tanaka, no. 409); Formosa: Hong-soang (H. Kawakami, no. 133); Heng.tsung, Tainan (C. Owatari); loco non indicato (Y. Tashiro no. 33.)

Calyx $3 \mathrm{~mm}$. altus, 5-partitus, subequalis, segmentis lineari-lanceolatis, setosis, seg. anticis 2 latioribus. Corolla hypocrateriformis, limbis intus glabris, extus villosis. Stamina 5, inclusa; filamentis nullis; antheris basi sagittatis. Stylus brevis, stigmate depresso-capitato. Fructus angulatus, dorso costatus.

Heliotropi um strigosum, Willd. D.C. Prodr. vol. IX. p. 546 ; Clark. in Hook. f. Fl. Brit. Ind. vol. IV. p. 151; Hemsl. Journ. Linn. Soc. vol. XXVI. p. 147; Henry in Trans. Asiat. Soc. vol. XXIV. Suppl. p. 63. 
Hab. Formosa: Shöka, Daichä in campis (Y. Tashiro, no. 74), Beilinzan (Y. Tashiro, no. 40); Formosa boreali (T. Makino); Byōlitsu (Honda no. 23).

Calyx 5-partitus, segmentis inæqualibus lanceolatis, extus adpresse strigosis. Corolla tubulosa vel hypocrateriformis, fauce parce barbatis, lobis ovalibus subacutis. Anthere ovate, acute, basi obtusee; filamentis brevissimis. Stylus staminibus brevior, stigmate conico. Nucule subtomentosæ.

Trichodesma (Friedrichsthalia) formosana, Matsumura sp. nov.

Planta 2-pedalis. Caulis crassus angulatus adpresse puberulus vel glabrescens. Folia petiolata, inferiora opposita, superiora oblanceolata, elliptica acuta basi attenuata, supra scabra sub lente setulis tuberculatis conspersa, subtus subpubscentia vel paree setulosa. Flores paniculati, longe pedicellati; calyx villosus, 5-lobatus, fructifer accrescens $32 \mathrm{~mm}-47 \mathrm{~mm}$. diametro, lobis ovato-lanceolatis acuminatis intus glabris; corollie tubus late cylindricus, 13 $\mathrm{mm}$. longus, $10 \mathrm{~mm}$. latus, extus 10-foveolatus, intus transverse 10-torulosus, lobis ovalibus longe acuminatis, tubo multoties brevioribus, reflexis; filamenta nulla ; anthere lanceolato-subulate sinistrorsum contorte, dorso tomentose. Ovaria depressa, glabra; stylus filiformis. $15 \mathrm{~mm}$. longus. Nucule ovate 6 mm. longe, dentato-marginate dorso laeves, ventre ruguloste.

Folia maxima suppetentia $390 \mathrm{~mm}$. longa, $160 \mathrm{~mm}$. lata, petiolis $6-40 \mathrm{~mm}$. longis suffulta. Panicula $120150 \mathrm{~mm}$. demum $240 \mathrm{~mm}$. longa, 120-240 mm. diametro; pedicelli 12 $20 \mathrm{~mm}$. longi.

Species T. calycosi Colli. et Hemsl. proxime affinis distat indumento omnibus cetrisque notis; $T$. Khasiani Clark, quoque affinis, differt corollee lobis brevioribus et latioribus.

Suffruticosa scandens cl. Tashiro adnotavit.

A cl. Henry Trans. Asiat. Soc. vol. XXIV. p. 63. sub. varietate 'T'. Khasiyani indicata ad hane speciem forsan referenda sit.

Hab. Formosa: in montosis ad Taichū (Y. Tashiro, no. 35); Tenkachilaisha, shū-shü-kai (C. Owatari).

Cynoglossum micranthum, Ilesf. D.C. Prodr. vol. X. p. 149; Maxim. Mel. Biol. vol. VIII. p. 555 ; Clark. in Hook. f. Fl. Brit. Ind. vol. IV. p. 156 ; Hemsl. Journ. Limn. Soc. vol. XXVI. p. 1.50 ; Henry l.c. 1. 63 .

Hab. insulis Oshima et Okinawa (Y. Tashiro); Formosa: Shinteck (T. Makino) Hoon-tsui (C. Owatari).

Bothriospermum tenellum, Fisch. et Mey. D.C. Prodr. vol. X. p. 
116 ; Benth. Fl. Hongk. p. 235 ; Maxim. Mel. Biol. vol. VIII. p. 560 ; Clark. in Hook. f. Fl. Brit. Ind. vol. IV. p. 167 ; Hemsl. Journ. Linn. Soe. vol. XXVI. p. 1.52; Henry l.c. p. 63.

Hab. insula Okinawa (Y. Tashiro); Formosa: Taipe (T. Makino), Byolitsu (Y. Tashiro), loco non indicato (C. Owatari).

Trigonotis peduncularis, Benth. Hemsl. Journ. Linn. Soc. vol. XXVI. p. 153 ; Eritrichium pedunculare, A. D.C. Prodr. vol. X. p. 128 ; Maxim. Mel. Biol. VIII. p. 548 ; Eritrichium japonicum, Miq. Prol. p. 28. Hab. insula Okinawa (Y. Tashiro).

\section{Contributions to the Knowledge of the forest Flora of Japan. I.}

By

M. Shirai.

(With Pl.V.)

In the course of studying Japanese forest fiora. I have met with many species of trees which were imperfectly described by the old writers and also with those entirely new, some to Japan and others to the world. But as trees are of large size and easy of detection, our botanists have already done so much toward their discrimination, that there remains but a few species to be newly discovered. Of the many imperfectly known trees, species of salix and Bamboos are the two large groups which require some renewed and careful study.

In the following paper, I intend to describe and illustrate such new or rare species of trees as I had the opportunity to examine during the last ten years, an interval of time during which I have spent almost every summer for botanical excursions throughout the empire except Formosa and Luchoo, in order to collect specimens for my study. All the illustrations rough as they are were made with my own pencil from the natural speci- 